\title{
Cartografia turística: o mapa como mediador na interpretação do território de Ouro Preto-MG
}

\begin{abstract}
RESUMO: O turismo deve ser estudado de modo especial pela cartografia, através da sistematização de uma cartografia do turismo, na qual o mais importante não é somente projetar símbolos para compor a legenda, e sim refletir sobre como esta deve ser organizada, a fim de expor claramente o raciocínio correto sobre o fenômeno, comunicando a verdadeira informação ao público que se utiliza desses mapas. Assim, buscou-se analisar as possíveis deficiências dos mapas turísticos de Ouro Preto-MG. Para tanto, o trabalho consistiu de referências e discussões teóricas que foram seguidas por uma análise de três diferentes mapas turísticos disponíveis sobre Ouro Preto, onde foi realizado o levantamento desses, sua abrangência e locais de divulgação. Com isto, esperou-se contribuir com a discussão sobre o mapa enquanto elemento mediador das experiências turísticas.
\end{abstract}

\section{Touristic cartography: the map as mediator in the interpretation of the territory of Ouro Preto-MG}

\footnotetext{
ABSTRACT: Tourism should be studied especially in cartography, through a systematic mapping of tourism, in which the most important is not only design symbols for writing the caption, but reflect on how this should be organized in order to express clearly correct reasoning about the phenomenon and report true information to the public that uses these maps. Therefore, was attempted to analyze the possible shortcomings of the tourist maps of Ouro Preto-MG. For this, the work consisted of theoretical discussions and references that were followed by an analysis of three different tourist maps available on Ouro Preto, which had undertaken the survey of these, its scope and local disclosure. With this, it was expected to contribute to the discussion on the map as a mediator of tourism experiences.
}

\section{Cleidison Vieira de Rezende}

Graduado em Turismo pela UFOP, pesquisador em Cartografia Turística, trabalhos em Cartografia Turística de Ouro Preto-MG.

\section{Palavras-chave: \\ Cartografia; Símbolos; Espaço; Turismo.}

Key-words:

Cartography, Symbols, Space; Tourism. 


\section{Introdução}

O turismo é uma atividade que comercializa o espaço, e a cartografia é o principal meio de representar tais ambientes. Por serem os mapas meios de comunicação entre o território e o turista, e seus símbolos importante elementos característicos, sem os quais nada se compreende (PEREIRA; DIAS; DALMOLIN, 1999), é que se propôs analisar os modelos de determinados mapas turísticos da cidade de Ouro Preto e suas possíveis relações com seus usuários.

Dessa forma, objetiva-se compreender as possíveis deficiências e facilidades de interação dos turistas com os mapas da cidade. A metodologia adotada consiste em pesquisas qualitativas dos principais mapas turísticos de Ouro Preto, onde, através de embasamento teórico, buscou-se observar e analisar esse material afim de que possa obter um maior número de informações complementares para a produção de um material cartográfico temático do turismo.

Após o entendimento dos elementos que compõem a cartografia, surge a necessidade de apresentar os elementos constituintes de um material cartográfico exclusivamente turístico, dentro do conceito de uma cartografia voltada para esse setor. Portanto, para uma análise no caso de Ouro Preto, buscou-se entender o espaço turístico da cidade, bem como os materiais cartográficos com maior representatividade. Com isto, o que se vislumbra é a geração de uma base de conhecimento para, futuramente, propor um mapa com pretensões idealistas, no que tange à localização para os turistas.

Embora existam diferentes representações cartográficas bem elaboradas, há, porém, muito que se desenvolver nesta área do turismo, uma vez que tais mapas são, na maioria das vezes, elaborados sem a visão e orientações de turismólogos que, por formação, são capazes de melhor compreender os anseios e necessidades dos turistas em visita a uma região. Dessa forma, surge a necessidade de analisar os atuais modelos de mapas turísticos, a fim de contribuir para uma maximização de suas funções.

Assim, discute-se no presente trabalho a necessidade de um mapa bem elaborado que apresente diversos fatores de identificação e seus devidos símbolos cartográficos, para uma melhor localização daquele que irá utilizá-lo.

\section{A Cartografia e o turismo}

Os primeiros relatos do surgimento da cartografia incidem com as culturas primitivas, mais precisamente com os homínidas, povos que se diferenciavam dos primatas pela sua postura vertical e a produção de ferramentas, que desenvolveram a relação de espaço, a partir de um eixo alto-baixo, no qual organizavam seu espaço ao redor do corpo humano e assim desenvolveram noções de frente e trás, direita e esquerda e cima e baixo. Cáceres (1996) reafirmava essa condição espacial dos homínidas que permitia a estes dividir seus

Geografia Ensino \& Pesquisa, v. 15, n.1, p. 17-28, jan./abr. 2011

Cartografia turística: o mapa como mediador na interpretação do território de Ouro Preto-MG 18 posteriormente com a criação dos animais domésticos, houve a necessidade de se traçar os itinerários que esses povos percorriam para levar o gado às zonas de pastagem e também nos seus grandes deslocamentos que se faziam necessários no curso das estações (AGUILAR, 1967). 
No Brasil, a história da cartografia é reflexo das técnicas cartográficas portuguesas, uma vez que o governo português já estava além de muitos outros na ciência da cartografia, devido às grandes navegações no século XV (AGUILAR, 1967). Com a descoberta do Brasil e chegada dos portugueses pelo litoral nordestino, houve necessidade de exploração do vasto território no intuito da descoberta de riquezas naturais e, consequentemente, metais preciosos. Duque e Mendes (2006) lembram que o governo português dedicou importante atenção à documentação cartográfica do Brasil, principalmente no que diz respeito ao limite com a América Espanhola, que poderia se tornar uma ameaça às suas terras. Finalmente, a então história cartográfica mais recente se remete à associação da cartografia à geografia, que se tornou mais humana e não somente conexa ao estudo da terra. Assim, somaram-se aos marcos da cartografia os mapas climatológicos, geológicos, hidrográficos e aqueles com características humanísticas como distribuição de raças, religiões, etnias, etc.

Nas suas técnicas atuais, a cartografia tem grande apelo simbólico, uma vez que os símbolos constituem-se de comunicação não-verbal, onde para decodificar sua mensagem é necessário identificar o signo e a sintaxe que o constituem e lhe dão realidade. 0 signo corresponde a uma combinação de um significante (conceito) e um significado (imagem mental), a sintaxe compreende as relações que as palavras estabelecem entre si nas orações e as relações que essas estabelecem entre si nos períodos. Chaui (1997) salienta que a "linguagem simbólica" realiza-se principalmente como imaginação, oferecendo sínteses imediatas (imagens), e seu outro tipo, a "linguagem conceitual", procura evitar a analogia e a metáfora, esforçando-se para dar às palavras um sentido direto e não figurado.

Dessa forma, surge a proposta dos símbolos cartográficos para o turismo, onde as fotografias ou desenhos representativos têm importante participação na elaboração dos signos iconográficos, que seria a representação por imagens (FIG. 1). Assim, através dos traçados, desenhos, cores, fotografias, os mapas são grande fontes simbólicas, com principal função de informar, devendo ater-se esses elementos, apenas às finalidades a que se destinam (MORANDI; GIL, 2002).

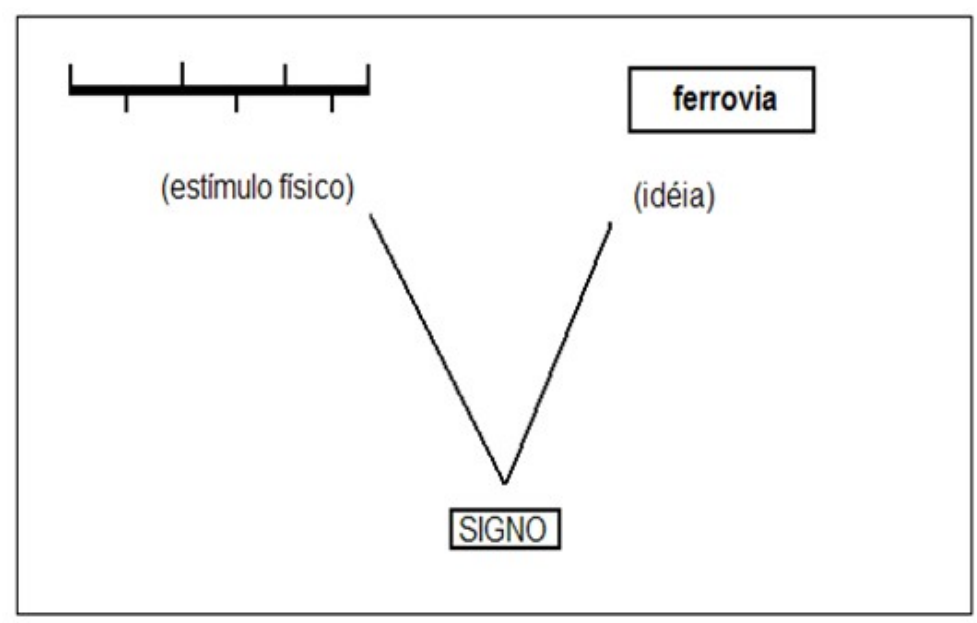

Figura 1 - Signo: idéia associada ao estímulo Fonte: Duarte, 1991, p. 27.

Considerando o mapa como um importante meio para a locomoção de turistas, no mesmo deve conter as devidas ligações que favoreçam a interação entre os nós (pontos turísticos) e as linhas (itinerário percorrido). No entanto, os pontos turísticos apresentam-se normalmente num contexto geral, que pela proximidade entre os atrativos, induz 0 turista a

Geografia Ensino \& Pesquisa, v. 15, n.1, p. 17-28, jan./abr. 2011

Cleidison Vieira de Rezende

ISSN 2236- 4994 
fazer suas próprias ligações, traçando seu próprio itinerário. Além disso, grande parte dos mapas turísticos elimina possibilidades extras de locomoção, uma vez que nem todas as linhas (ruas, becos, praças, etc.) são apresentadas e, dessa forma, extingue a utilização de novos caminhos.

Dessa modo, a necessidade da utilização dos símbolos nas produções cartográficas é fundamental, pois enriquecem os mapas e, constituem-se hoje, como fator somatório para modernização da produção dos mesmos. Como apresentado anteriormente em seu histórico, os mapas adquiriram, ao longo do tempo, subsídios que facilitaram a sua utilização: a partir de uma placa de barro cozido, apresenta-se atualmente como um complexo emaranhado de informações, imagens e mensagens.

\section{Elaboração de Mapas turísticos}

O objetivo inicial da cartografia consiste em expressar, sobre um sistema plano de coordenadas, pontos que tenham perfeita ligação com seu homólogo na superfície terrestre, de tal forma que o cálculo efetuado mantenha perfeita correspondência quando transportado para a superfície original. Essa representação de superfície terrestre sobre o plano, devido a sua facilidade de manejo, interessa sobre maneira nos estudos da topografia, habitação, climatologia, vegetação, turismo, etc. 0 método de projetar ou representar pode ser classificado de duas maneiras: projeção direta, que é a transformação do elipsóide diretamente para a superfície de projeção; e projeção indireta, onde envolve duas transformações, do elipsóide para a esfera e da esfera para a superfície de projeção. Quanto aos tipos de superfície de projeção, subdividem em três: plana, cônica e cilíndrica, sendo todas perfeitamente desenvolvíveis no plano (SANTOS, 1985).

Duarte (1991) subdivide a cartografia em dois grandes ramos: Cartografia Geral e Temática. No primeiro, incluem-se os mapas de uso geral, no segundo, os mapas destinados a público específico ou especial. Entretanto, considera quase impossível traçar uma linha demarcatória para dizermos se determinado trabalho constitui preocupação de uma ou de outra. Em seus trabalhos, a Cartografia Temática inicia-se de um "fundo básico" ou "mapa de fundo", que nada mais é do que o conjunto de traços que servirá de suporte para a informação a ser dada sobre determinado tema através de simbologia adequada.

Loch et al. (2005), se atenta à questão de determinados critérios no que diz respeito à elaboração de um mapa temático, como é caso do mapa turístico. Pois, mesmo com todo o aparato tecnológico atual, muitas vezes, os mapas não atendem aos critérios da cartografia de base e da cartografia temática. Dessa forma, deve-se buscar uma maior interação entre 0 mapa e o usuário, ressaltando elementos que vão distinguir o mapa de outro desenho qualquer, como a escala e a projeção cartográfica, coordenadas, legenda ou convenções cartográficas, e do título, nessa ordem de importância.

De modo geral, a constituição de um mapa temático se dá colocando a idéia principal em

Geografia Ensino \& Pesquisa, v. 15, n.1, p. 17-28, jan./abr. 2011

Cartografia turística: o mapa como mediador na interpretação do território de Ouro Preto-MG interesse, ser preciso, ter seus elementos de modo organizado, de forma a facilitar a decodificação do receptor. Assim, numa representação cartográfica o artístico e o científico devem compor um conjunto harmonioso, visando satisfazer o leitor não somente com a beleza do trabalho, mas também com o nível de das informações fornecidas (DUARTE, 1991). 
De acordo com Muscarà ${ }^{1}$ (apud MARTINELLI, 1996, p. 296), o espaço turístico responde sempre a um intricado complexo de informações, imagens e mensagens. Dessa forma, na construção de um mapa turístico com a finalidade de comunicação, é importante levar em consideração a sua expressividade, isto é, a capacidade de atrair a atenção do leitor aos aspectos abordados pelo mapa, valorizando os pontos importantes que estejam relacionados ao tema abordado, destacando as relações hierárquicas do local estudado.

A cartografia utiliza-se de meios, que somados à imagem, auxiliam no processo de comunicação dos mapas, favorecendo a interpretação pelo receptor do que está sendo representado, como: título e subtítulo, que expressa o que está representado no mapa, qual porção da superfície terrestre, qual território e o que está sendo reproduzido, se é hidrografia, relevo, topografia, entre outros; a legenda, extremamente importante por fazer a ligação entre os significantes, gráficos e o significado; a escala, que representa as relações entre as distâncias lineares medidas no terreno, permitindo a precisão dos detalhes em função das necessidades do usuário; as orientações, que são os indicadores cardeais, coordenadas geográficas (latitude, longitude, etc.) (DUQUE; MENDES, 2006).

A representação da cartografia do turismo através das imagens se torna incontestável, uma vez que esse tipo de registro fixa certas características da realidade, com o propósito de ilustrar o que o texto "diz". Lacoste (1976) salienta a importância de se associar as fotos ou desenhos aos mapas, pois estes representam a totalidade do espaço, enquanto a paisagem registrada pelas imagens pode apresentar espaços escondidos em função da disposição do observador. Por outro lado, deve-se atentar a essa prática, pelo fato das imagens fotográficas ou desenhos apresentarem forte caráter polissêmico (significados múltiplos). Dessa forma, surge a necessidade de associar a mesma a um título, slogan, ou legenda (MARTINELLI, 1996).

Para uma melhor interpretação, o uso de legendas nas fotografias pode complementar o mapa ou texto turísticos. Martinelli (1996) sugere um esquema reduzido colocado ao lado da legenda, identificando e esclarecendo os itens registrados pelo enquadramento da ilustração, como que encaminhando o usuário para uma leitura da paisagem consciente: será decomposta em seus conjuntos paisagísticos mais significativos, organizados em contínuos planos visuais. Desse modo, se torna necessária a inserção de desenhos ou imagens fotográficas aos mapas, para que este possa adquirir maior alcance social no turismo, possibilitando sua interpretação por um número maior de usuários. Loch et al. (2005) apresenta um exemplo do que poderia ser um mapa temático turístico completo, de uma cidade hipotética (FIG. 2).

Por fim, a cartografia do turismo deve se basear em elementos que contribuam para uma melhor comunicação do produto cartográfico e o turista, através da coleta, tratamento, análise e representação de dados que possam proporcionar um grande número de informações de qualidade e precisão na produção dos mapas. Dessa forma, é desejável que o mapa do turismo reúna três formas de comunicação, como o mapa, o texto e a foto. Tornando evidente o ponto de encontro equilibrado do sistema semiológico monossêmico (mapa) com os sistemas polissêmicos (texto e foto) (MARTINELLI, 1996).
1 MUSCARÀ, C. Gli spazi del turiso. Bologna, 1983 


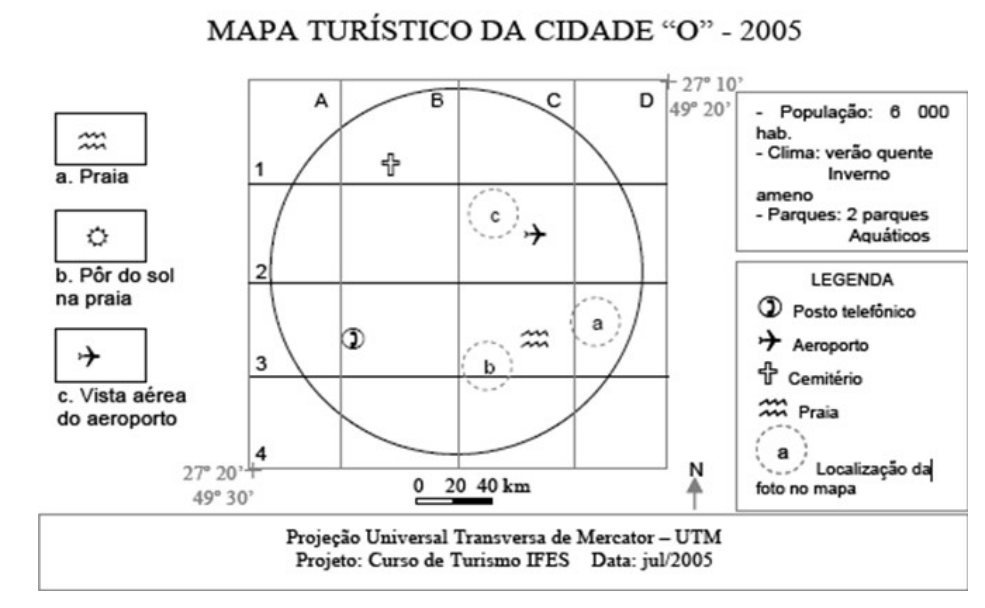

Figura 2 - Exemplo de mapa temático turístico Fonte: Loch, et al., 2005, p. 12.

\section{Análise exploratória dos mapas turísticos de Ouro Preto}

${ }^{2 h}$ htp://www.braziltour.com/site/br/ cidades/materia.php?id_cidade=1 055

${ }^{3 h t t p: / / w w w . t u r i s m o . m g . g o v . b r / i n d ~}$ ex.php?option=com_content\&task =view\&id=7

Geografia Ensino \& Pesquisa, v. 15, n.1, p. 17-28, jan./abr. 2011

Cartografia turística: o mapa como mediador na interpretação do território de Ouro Preto-MG
A cidade de Ouro Preto está inserida dentre os principais destinos turísticos de Minas Gerais, e se destaca também no cenário nacional e internacional, conforme dados da EMBRATUR $^{2}$ (Instituto Brasileiro de Turismo). Localizada a aproximadamente 100 quilômetros de Belo Horizonte, a cidade está na Serra do Espinhaço e se encontra em uma das regiões de maior importância econômica do estado, a Zona Metalúrgica de Minas Gerais (Quadrilátero Ferrífero). Ouro Preto atrai muitos turistas principalmente pela sua história e arquitetura, constituindo o maior conjunto homogêneo de arquitetura barroca do Brasil. 0 turismo se compõe principalmente pelo cultural, histórico e turismo de eventos.

Ouro Preto, por apresentar um relevo muito irregular, dificulta a fruição tanto de pedestres e principalmente no trânsito de veículos. No geral, suas ruas são predominantemente ruelas, possuem minúsculas calçadas e às vezes nem isso. Além disso, existem na cidade becos que se constituem como verdadeiras vilas, com um aglomerado de casas no seu interior, que servem de ligação entre ruas, travessas e até mesmo bairros. Um exemplo disso são os Becos das Rosas e o das Flores, ambos situados no bairro da Barra. Outro exemplo é o Beco do Pilão, localizado entre Câmara Municipal de Ouro Preto e o prédio da FIEMG (Federação das Indústrias do Estado de Minas Gerais), antigo Hotel Pilão, que liga a Praça Tiradentes à Rua dos Paulistas no bairro Antônio Dias. Em sua grande maioria, esses são utilizados somente pela população que tem conhecimento de sua existência.

Em virtude desses fatores é que se propôs fazer o levantamento dos principais mapas turísticos de Ouro Preto, bem como os principais pontos de acesso turístico onde esses mapas são disponibilizados. Os mapas foram selecionados conforme análise realizada na Secretaria Municipal de Turismo de Ouro Preto, que de acordo com a mesma, existem dois tipos de mapas turísticos que possuem uma maior circulação na cidade. Um desses é 0 próprio mapa produzido pela Secretaria de Turismo juntamente com a Prefeitura Municipal de Ouro Preto (FIG. 3), o outro é produzido por Walter Peret através da Ponto de Apoio Topografia, encontrado nos principais meios de hospedagem e papelarias da cidade (FIG. 4). A FIG. 5 apresenta o terceiro e último mapa, associado ao Guia Brasil 4 Rodas, uma vez que esse material é bastante consultado por grande parte dos turistas brasileiros e estrangeiros. De acordo com pesquisas realizadas pela Secretaria Estadual de Turismo de Minas Gerais ${ }^{3} 0$ 
Guia Brasil 4 Rodas é um meio bastante recorrido pelos turistas, isso pelo fato de conter não somente material cartográfico mas também pelo grande acesso a informações turísticas como equipamentos e serviços turísticos em geral, no mais variados idiomas, principalmente inglês, espanhol e francês.

Uma vez definido o material cartográfico, procurou-se realizar uma análise exploratória do mesmo, como tiragem, locais de distribuição, formas de acesso desse material para os turistas, e finalmente, se esses mapas são distribuídos gratuitamente ou não. 0 mapa produzido pela Secretaria Municipal Turismo possui uma tiragem de 50 mil exemplares anualmente, sendo realizadas duas tiragens de 25 mil em cada semestre e possui distribuição gratuita. Dentre os pontos de distribuição estão: o Centro de Informações Turísticas na entrada da cidade, saída para Belo Horizonte; o Posto de Informações Turísticas da FIEMG, localizado na Praça Tiradentes no prédio da FIEMG; e eventuais necessidades, como distribuição em congressos e demais eventos onde possa haver demanda dos mesmos.

O mapa produzido pela Ponto de Apoio Topografia possui uma tiragem anual de 1.000 mapas, são vendidos aos principais equipamentos e serviços turísticos, como meios de hospedagem e restaurantes da cidade para serem distribuídos gratuitamente para os turistas, e são revendidos em papelarias e armarinhos a um preço de $R \$ 2,00$ (dois reais).

O Guia Brasil 4 Rodas 2006, de acordo com a Editora Abril de Belo Horizonte, teve uma tiragem de 230 mil exemplares, sendo parte dessa em outros idiomas, e as edições de 2007 e 2008 tiveram uma tiragem de 240 e 250 mil exemplares, respectivamente. Sua distribuição é feita através das bancas de revistas e vendas na internet pelas grandes editoras do país, onde o usuário pode adquirir o material pelo preço de $R \$ 35,00$ (trinta e cinco reais) a edição de 2008.

Dessa forma, através de pesquisa realizada das demais variadas formas, como internet, contato por telefone, contato direto com responsáveis, é que se constatou que esses três materiais cartográficos são de grande relevância no que diz respeito à utilização dos turistas, julgando-se necessária a análise dos mesmos.

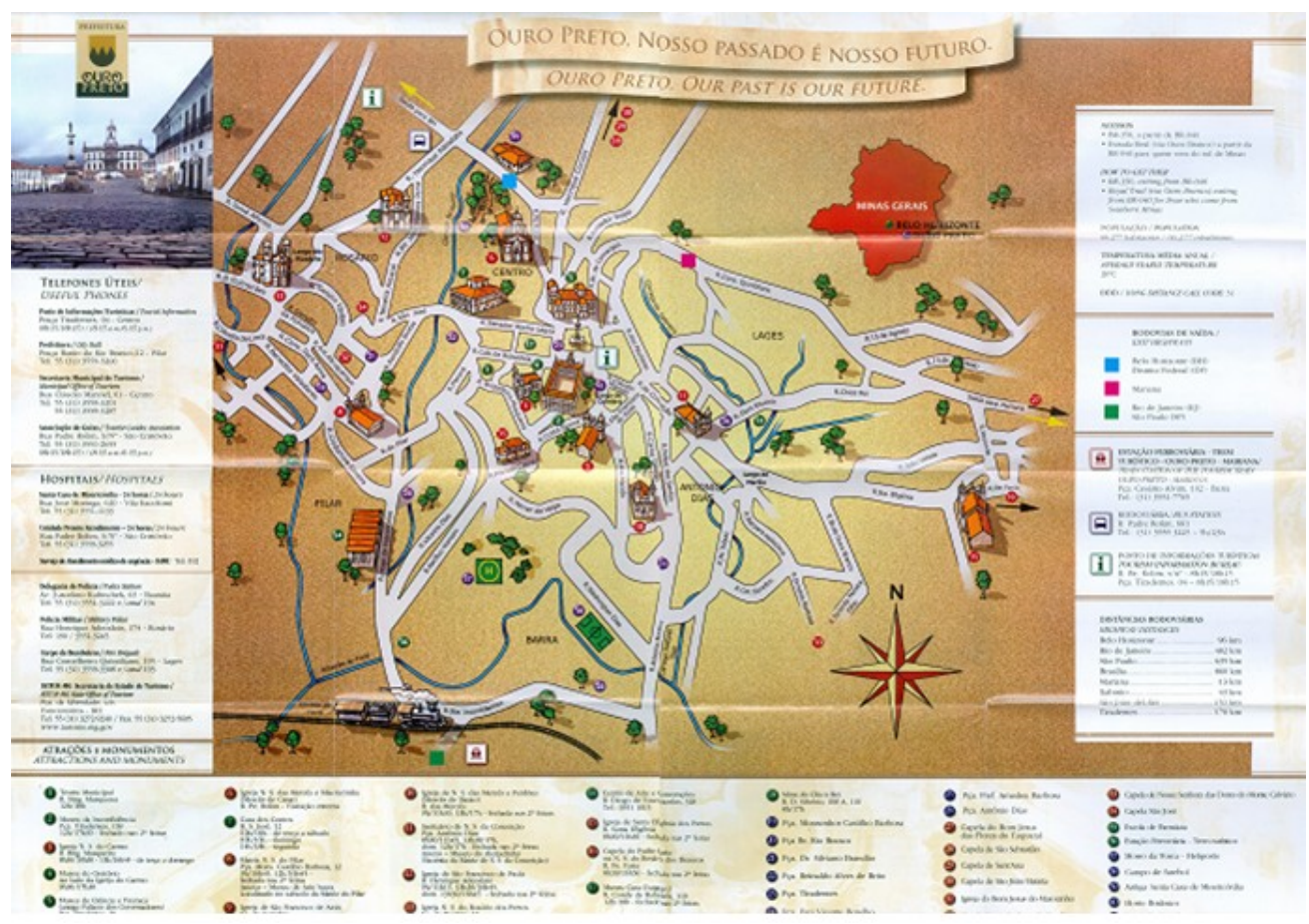

Geografia Ensino \& Pesquisa, v. 15, n.1, p. 17-28 jan./abr. 2011 


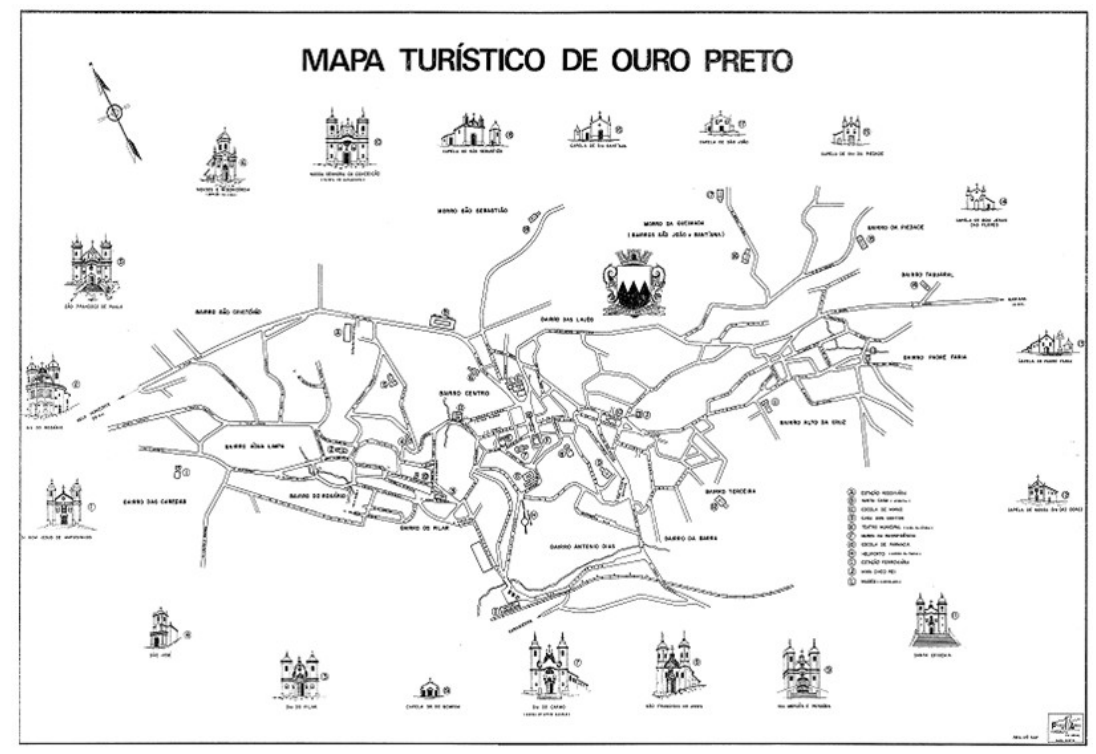

Figura 4 - Mapa turísitico de Ouro Preto (Meios de hospedagem)

Fonte: PERET, Walter. Mapa turístico de Ouro Preto. Ouro Preto, 2008. Mapa turístico.

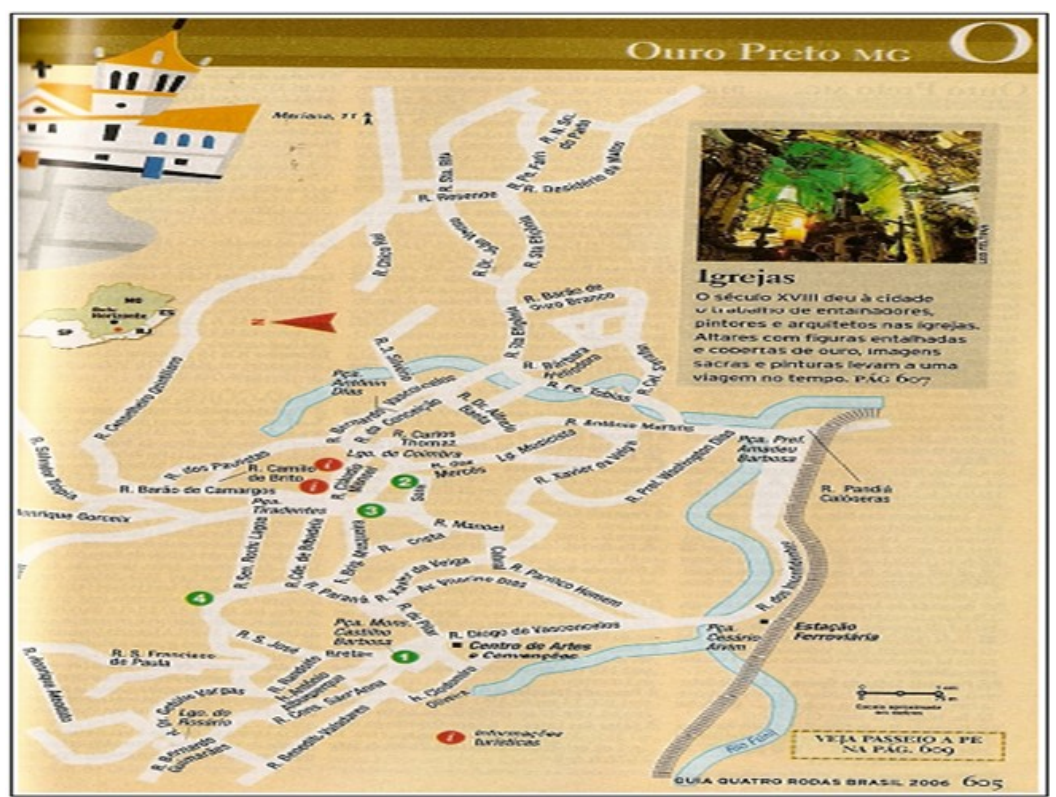

Figura 5 - Mapa turísitico de Ouro Preto (Anexo ao Guia 4 Rodas)

Fonte: Guia Brasil 4 Rodas. Mapa Turístico de Ouro Preto. Abril, 2006, p. 605.

Geografia Ensino \& Pesquisa, v. 15, n.1, p. 17-28, jan./abr. 2011

Cartografia turística: o mapa como mediador na interpretação do território de Ouro Preto-MG

Após a pesquisa que possibilitou definir o material cartográfico de interesse, surge a necessidade de analisar cada mapa em sua especificidade e, dessa forma, poder compreender a sua contextualidade através dos dados que estes dispõem.

Portanto, o primeiro material selecionado para essa observação foi o mapa turístico distribuído pela Secretaria Municipal de Ouro Preto. Esse mapa se constitui de uma mini cartilha informativa, contém não somente a representação cartográfica mas também informações em seu verso como calendário de eventos, telefones úteis da cidade, opções de ecoturismo, indicação de alguns distritos da cidade de Ouro Preto, dicas de como utilizar os produtos turísticos, entre outros. Essas informações, disponibilizadas também no idioma inglês, possibilitam melhor interpretação do local pelo turista e, conseqüentemente, causam maior interação e empatia entre ele e o mapa (MURTA; ALBANO, 2002). 
Entretanto, ao possibilitar informações que são de alta relevância para a interpretação, 0 produtor do mapa suprime outros dados como as coordenadas geográficas e marcação da escala, que orientam o usuário com noções de direção e distância. Duque e Mendes (2006) salientam que o mapa deve direcionar seu usuário, permitindo que o mesmo possa calcular a distância de um ponto ao outro, e dessa forma fazê-lo sentir inserido no espaço turístico. Outra deficiência encontrada foi a ausência do título, pois esse material não se identifica como "mapa turístico", uma vez que é de fundamental relevância apresentar o que está sendo reproduzido no mapa através de seu título e subtítulo. Julga-se também, de extrema importância, a utilização dos signos iconográficos (imagens) na representação dos pontos turísticos, pois de acordo com Martinelli (1996) os mapas que se utilizam de fotografias representativas acabam dispensando o uso da legenda, facilitando sua comunicação. 0 mapa produzido pela Secretaria de Turismo se utiliza apenas de desenhos que às vezes distorcem a sua forma real (FIG. 6).

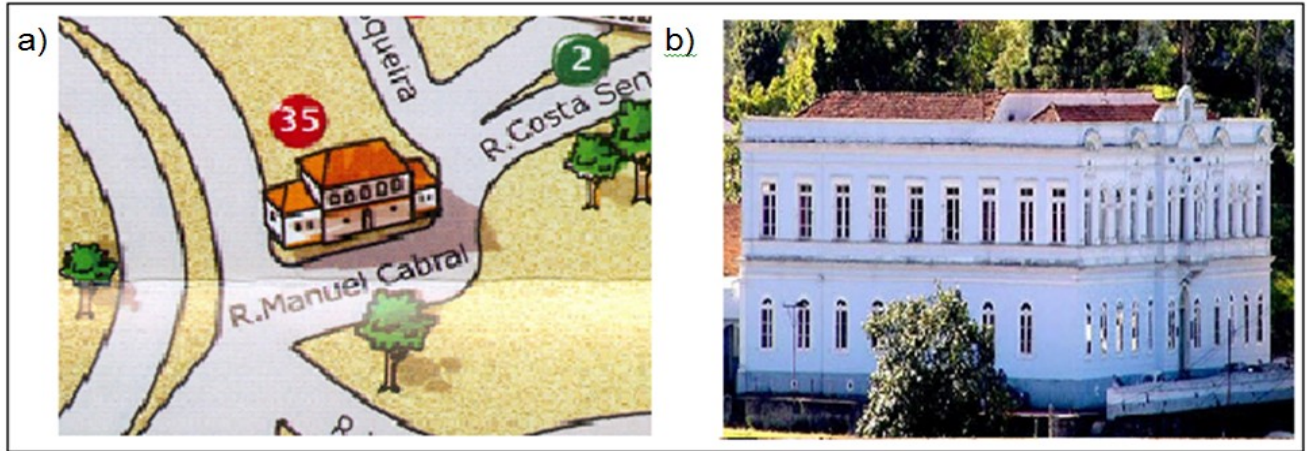

Figura 6 - Representação distorcida da Escola de Farmácia de Ouro Preto

a) Escola de Farmácia representada no mapa

b) Imagem real da Escola de Farmácia

Fonte: a) SECRETARIA MUNICIPAL DE TURISMO DE OURO PRETO. Mapa turístico de Ouro Preto. Ouro Preto, 2007. Mapa turístico.

b) ESCOLA DE FARMÁCIA DE OURO PRETO. Disponível em: <http://www.ef.ufop.br/> Acesso em: 25 junho 2008.

O segundo material analisado foi o mapa produzido pela empresa de topografia Ponto de Apoio, onde o mesmo se constitui somente como produto cartográfico em si. 0 mapa é composto de legenda, importante meio que faz a ligação entre significante e significado; título, onde identifica o que está sendo representado no material em questão; imagens dos monumentos religiosos, que apesar de se apresentarem em forma de desenho, conseguem reproduzir com bastante detalhes a realidade, e possuem indicação na legenda; e orientação, onde se encontra no cabeçalho superior esquerdo um indicador cardeal.

Apesar de apresentar itens com grande potencial informativo, esse material cartográfico é destituído de elementos que poderiam contribuir para uma melhor disposição estética e funcional dos seus dados. Mesmo possuindo os indicadores cardeais, o mapa deveria conter na sua composição elementos como as coordenadas geográficas, pois de acordo com Loch et al. (2005), a falta de tais impossibilita a distinção do mapa com outro desenho qualquer. Repetindo o exemplo do primeiro mapa turístico analisado, este não apresenta marcação de escala, dessa forma poderá causar situações indesejadas aos turistas no que diz respeito ao cálculo das reais distâncias. Outro fator encontrado na análise foi a falta de identificação de ruas e becos, em locais com pouco fluxo turístico, e também em locais de alto fluxo, como no caso do Centro Histórico da cidade (FIG. 7).

Portanto, a ausência na identificação desses elementos como os becos faz com que haja diminuição de possibilidades extras de locomoção dos turistas, e dessa forma extinguindo a

Geografia Ensino \& Pesquisa, v. 15, n.1, p. 17-28, jan./abr. 2011

Cleidison Vieira de Rezende

ISSN 2236- 4994 
utilização de novos caminhos que possam ser percorridos. Entretanto, quando se identifica todos esses elementos, corre-se o risco do mapa ficar sobrecarregado visualmente, causando confusão entre seus usuários.

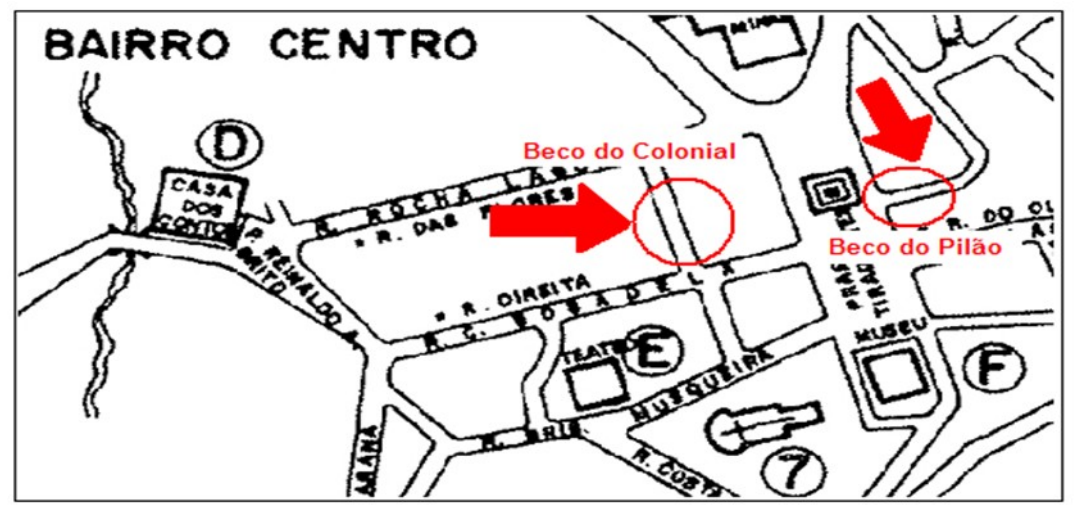

Figura 7 - Ausência de identificação dos Becos do Pilão e Colonial

Fonte: PERET, Walter. Mapa turístico de Ouro Preto. Ouro Preto, 2008, grifo do autor.

Finalmente, ao analisar o Guia Brasil 4 Rodas considerou-se não somente o produto cartográfico em si, mas também a sua funcionalidade como um guia turístico. 0 mapa é constituído de legenda, representando os principais pontos turísticos como monumentos religiosos e museus. Cada igreja e museu representados são complementados por sua respectiva foto em outras páginas do guia, contribuindo para uma maior interpretação da realidade, pois de acordo com Lacoste (1976), essa associação atrativo-imagem representa a totalidade do espaço de forma mais completa; possui indicador cardeal no que diz respeito à sua localização; e é composto de marcação de escala, fator importante na identificação do material representado em sua constituição como um mapa (LOCH et al., 2005).

No que diz respeito às suas deficiências, o mapa não possui título e dessa forma não se denomina de material cartográfico, apesar de seu contexto estar inserido num guia turístico. 0 mapa não possui coordenadas geográficas, que quando associadas aos indicadores cardeais, compõem um importante meio para localização dos seus usuários. Por fim, o material em questão, além de não identificar elementos como ruas e becos, exclui a própria existência dos mesmos, como demonstrado na FIG. 8. Essa omissão desses fatores causa, na mesma intensidade do excesso, confusão para quem se utiliza desse mapa, e dessa forma perder credibilidade entre esses usuários.

Geografia Ensino \& Pesquisa, v. 15, n.1, p. 17-28, jan./abr. 2011

Cartografia turística: o mapa como mediador na interpretação do território de Ouro Preto-MG

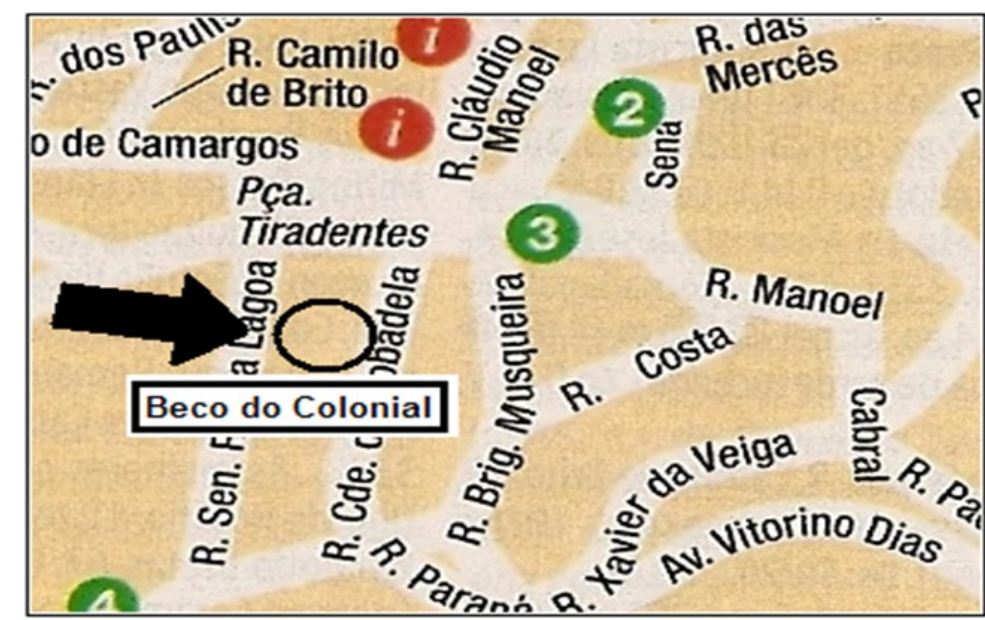

Figura 8 - Omissão do Beco do Colonial

Fonte: Guia Brasil 4 Rodas. Mapa Turístico de Ouro Preto. Abril, 2006, grifo do autor, p. 605. 
Em virtude dos fatores mencionados, os três mapas analisados apresentam fatores positivos e negativos na sua constituição. Dessa forma, propõe-se elaborar um material cartográfico com 0 intercâmbio de todas as informações positivas encontradas nesses materiais em questão. Assim, esse modelo de mapa turístico deveria ser constituído de: título e subtítulo; legenda de todos os elementos representativos; escala numérica; indicadores cardeais, coordenadas geográficas; e principalmente composto por elementos semiológicos (imagens). Desse modo, pode-se associar todas essas características através de uma disposição harmônica para, assim, evitar sobreposição e, consequentemente, confusão na sua interpretação.

\section{Considerações Finais}

A interpretação dos espaços requer de seu agente, em suas mais variadas formas, um grande esforço para tal, uma vez que são envolvidos fatores culturais, históricos, físicos, dentre outros. E no espaço turístico, ao ser representando pela cartografia, salienta-se a sua interpretação pelo viés da comunidade local e do turista, pois dessa forma pode ser concebida a realidade da primeira e os anseios lúdicos adquiridos pelo segundo.

A partir do desenvolvimento do presente trabalho, pode-se concluir que os objetivos traçados foram atingidos, ou seja, o levantamento dos mapas turísticos de Ouro Preto de maior abrangência e seus locais de divulgação, bem como a análise dos seus fatores positivos e negativos. No mais, o entendimento da contextualização do mapa turístico e seus componentes foram também contemplados e desenvolvidos dentro do conceito turístico. Para tanto, alguns conceitos cartográficos e simbológicos foram discutidos no que tange a confiabilidade da comunicação cartográfica das informações turísticas. Dessa forma, a metodologia proposta seguiu conceitos pesquisados sobre o assunto e mostrou que, apesar de existirem variados produtos cartográficos turísticos de Ouro Preto, os materiais analisados se destacam dentre todos pela quantidade do público atingido.

A análise dos materiais cartográficos turísticos de Ouro Preto provou que os mesmos possuem deficiências em sua elaboração, omitindo elementos que são de fundamental importância para uma perfeita comunicação do mapa com o turista. Entretanto, como a Cartografia Turística4 possui imensa potencialidade, é que se recomenda a atualização desse trabalho através de uma fração temporal de curto prazo. Assim, possibilita-se que este não se prenda a antigos conceitos cartográficos e que o mesmo possa ser aplicado em outras destinações turísticas. Além disso, uma entrevista com os produtores desses mapas seria de grande relevância para obter informações detalhadas dos mesmos.

Finalmente, ao fornecer embasamento teórico para que se desenvolva um mapa turístico, recomenda-se como proposta futura a produção de um mapa turístico de pretensão ideal. Dessa forma, testar esse mapa através uma pesquisa de campo levando um grupo de turistas a interagir com esse mapa e, assim, avaliar os resultados obtidos, seria de grande contribuição na continuação dessa pesquisa.

Assim sendo, a Cartografia do Turismo consegue agregar dois conceitos: arte e ciência. Ciência por estar a serviço de várias outras ciências, por constituir um conjunto de operações como a transformação da superfície curva da Terra até a busca da melhor simbologia para representar os mais variados fatos dessa mesma superfície. Arte pelo fato do cartógrafo

Geografia Ensino \& Pesquisa, v. 15, n.1, p. 17-28, jan./abr. 2011

Cleidison Vieira de Rezende 
buscar oferecer uma informação do modo mais adequado, através da linguagem gráfica, respeitando as regras da semiologia gráfica e sem esquecer-se da ótica da estética, visando atingir 0 ideal de beleza, mas sempre buscando harmonia entre 0 artístico e o científico.

\section{Referências Bibliográficas}

AGUILAR, José. Georama. 1. ed. Rio de Janeiro: Codex, 1967.

CÁCERES, Florival. História geral. 4. ed. São Paulo: Moderna, 1996.

CHAUI, Marilena. Convite à filosofia. 8. ed. São Paulo: Ática, 1997.

DUARTE, Paulo Araújo. Cartografia temática. 1. Ed. Florianópolis: Ed. da UFCS, 1991. 145 p.

DUQUE, Renato Câmara; MENDES, Catarina Lutero. 0 planejamento turístico e a cartografia. 1. Ed. Campinas: Alínea, 2006.

EMBRATUR "Portal Brasileiro do Turismo". Apresenta produtos e serviços turísticos oferecidos pelo Brasil. Disponivel em: <http://www.braziltour.com/site/br/cidades/materia.php?id_cidade=1055>. Acesso em: 19 jun. 2008.

LACOSTE, Y. La géographie ça sert d'abord pour faire la guerre. Paris: Maspero, 1976.

LOCH, Ruth E. N.; OLIVEIRA, Kênya N.; RECH, Claudia M. C. B. Orientações para elaborar um mapa temático turístico. Disponível em:

<http://www2.ifes.com.br/webifes/revista/Files/ORIENTA\%C7\%D5ES\%20PARA\%20ELABORAR\%20UM\%20 MAPA\%20TEM\%C1TIC.pdf>. Acesso em: 12 jun. 2008.

MARTINELLI, Marcelo. Cartografia do turismo: que cartografia é essa? In: Lemos, Inês G. de. Turismo: Impactos Socioambientais. São Paulo: Hucitec, 1996.

MENEZES, P. M. L.; FERNANDES, M. C. Cartografia turística: novos conceitos e antigas concepções ou antigos conceitos e novas concepções. Revista Brasileira de Cartografia, n. 60/01, 2008. Disponível em: <http://www.rbc.ufrj.br/_2008/60_1_01.htm>.Acesso em: 13 jun. 2008.

MORANDI, Sonia; GIL, Izabel Castanha. Espaço e turismo. 2. ed. São Paulo: Copidart, 2002.

MURTA, Stela Maris; ALBANO, Celina. Interpretar o patrimônio: um exercício do olhar. Belo Horizonte: Ed. da UFMG; Território Brasilis, 2002. 288p.

PEREIRA, Adriana C. F.; DIAS, Luiz A. V.; DAMOLIN, Quintino. Elaboração de símbolos cartográficos para mapas turísticos em meio digital. Boletim de Ciências Geodésicas, Curitiba, v. 5, p. 3-14, 1999.

SANTOS, Adeildo Antão dos. Representações cartográficas. Recife, Universidade Federal de Pernambuco, Ed. Universitária, 1985. 201p.

\section{Correspondência}

Cleidison Vieira de Rezende- Rua Lausanne, 29-B. Bairro Bethânia, Ipatinga-MG. CEP 35164-072.

E-mail: cvr.geo@gmail.com

Geografia Ensino \& Pesquisa, v. 15, n.1, p. 17-28, jan./abr. 2011

Cartografia turística: o mapa como mediador na interpretação do território de Ouro Preto-MG
Recebido em 08 de novembro de 2010

Revisado pelo autor em 11 de março de 2011

Aprovado em 09 de junho de 2011 